\title{
The Value of Cultural Immersions in Teaching Mandarin as a Second Language
}

\author{
Nuraini Jafri*, Umi Kalthom Abd Manaf, Mohd Mokhtar Muhamad \\ Department of Foundations of Education, Faculty of Educational Studies, Universiti Putra Malaysia, Malaysia
}

Received October 27, 2019; Revised December 2, 2019; Accepted December 24, 2019

Copyright $\odot 2020$ by authors, all rights reserved. Authors agree that this article remains permanently open access under the terms of the Creative Commons Attribution License 4.0 International License

\begin{abstract}
Over centuries, English has become the dominant language throughout the world. The role of English in many areas such as education, politics, business, science, and technology is undeniable. Nonetheless, the explosive growth of China as one of the world leading powers has caused many people to be in an "alert" state especially in embracing Mandarin as a second language. Although it seems plausible to accept Mandarin as a second language, the language however could be very difficult for one to master. There are four main components of learning Mandarin, which are reading, writing, listening and speaking. Therefore, this concept paper discusses the role of culture as one innovation in teaching and learning processes. Through the discussion in the paper, the authors hope to instill the idea of immersions of culture in the curriculum for the betterment of the students in acquiring Mandarin as a second language.
\end{abstract}

Keywords Mandarin Language, Second Language, Culture, Cultural Immersion

\section{Introduction}

Language plays a significant role in human daily life as it is one of the main ways of communicating and interacting with people. Language is essential in helping people expressing their feelings, beliefs, knowledge, opinions, declaration etc. (Amberg \& Vause, 2009). According to the Malinowski's Theory (1923), language is best illustrated as the fundamental means of communion; it is a very imperative instrument in creating ties of the moment without which unified social action is absurd (Duncan, Duncan \& Wilder, 2017). Thus, language plays an important role in human lives as it serve basic principle of actions, building ties of purely social communion, and even conveying ideas and feelings of the speaker.
Given the diversity of human population, there is an urgency to have a common language of communication. The ongoing process of globalization has made the condition more crucial to have a common language specially to overcome the intercultural and interlingua barriers in integrating nations to form a common economic and cultural area (Smokotin, Alekseyenko and Petrova, 2014).

Back then, prior to the European Renaissance, Latin was the lingua franca (Boyd, William and King, 1995). French also was once a global language during the 16th century owing to the French colonialism (Mufwene, 2006). However, at present, English language has acquired the status of lingua franca due to the long history of British colonization and American cultural imperialism (Jenkins, 2014; Seidlhofer, 2015). In fact, having people to able to communicate in English nowadays has become a norm. English language has been widely used in many countries across the world as the main medium in the fields of business (Neeley, 2012), academics (Dearden, 2015), education (Fenton-Smith, Humphreys \& Walkinshaw, 2018), sciences (Drubin \& Kellogg, 2012), politics (Orwell, 2013) and even entertainment (Crystal, 2003). Thus, with all the scenarios explained above have made English language has turned into one of a major competencies of an individual.

\section{The Arrival of Second Lingua Franca}

There's a saying "the sky will not always be blue; the sun will not forever shine all day long". So does with the English language position as lingua franca since we are living in a dynamic world; keeps evolving without waiting for us to cope with the changes that took place. For decades, the English language has been conquering the major areas globally due to the position of United States as the world's only superpower especially in military, political and economic (Adelman, 2013).

On the other side of world, there's another country 
keeps rising up, creating name, aggressively conquering the world. China's rapid economic growth from a poor developing country to a major economic power has been very remarkable. Currently, China is the world's largest source of imports, largest merchandise trading partner of United States and third-largest export market (Morrison, 2011). The emergence of China as one of the world economic powers has been spreading the demand of Mandarin language. The need to converse the language especially in economical fields is extensively necessary for one to compete and survive in the ever-changing dynamic world.

According to a study done by David Graddol (1997), he proposed that the language of Chinese people will become one of the world's top languages by 2050 due to the increasing global importance of China economically and culturally. Mandarin is the sole official language of the People's Republic of China (Wang \& Lemmer, 2013). For the past three decades, the number of Mandarin learners as a second language or foreign language has productively increasing. Based on the statistical data gained from Hanban, as of 2017 there are more than forty million learners of Mandarin as a non-native language (Zhao, 2017).

From the international scene to the national context, the importance of Mandarin is unquestionable. Recently, the Malaysia's Parti Keadilan Rakyat president, Datuk Seri Anwar Ibrahim notably urged Malay youths to master the Mandarin language as it is an important regional "economic language" during the seminar on "The Vision of the New Malaysia Aspiration" (Bernama, 2018). Even the Malaysia Prime Minister's Department, Dr Mujahid Rawa also sent his daughter to further study in Mandarin as he foresees the importance of Mandarin language (Khor Chun Keat, 2018).

The big tsunami wave made by China pushes Mandarin language to become the new second lingua franca (David, 2006). According to the statistical data on the world's most spoken languages, Mandarin language is the most spoken language across the world with more 1.3 billion speakers, leaving behind Spanish, Arabic, and Russian etc. (McCarthy, 2018). Thus, undoubtedly, day by day Mandarin itself is strengthening its world-wide as many people have begun to acquire Mandarin as their second language (Goh, 2016).

\section{The Nature of Mandarin Language}

Mandarin as a second language is the study of Chinese or Mandarin language by non-native speakers. The learning of Mandarin language is not only regarding the phonological structure and orthographic feature; in fact it is beyond these alphabetic phonetic systems (Abro, Zhenfang \& Shabbir, 2014). The learning of Mandarin language emphasizes on the development of learners' reading skills, writing skills, listening comprehension skills and speaking skills (Spencer, 2015).

There are many researches regarding the Mandarin language acquisition as second language. Mandarin language is known as one of the most difficult language to acquire (Hong \& Moreira, 2002). In another study, it mentioned that one of the most challenging parts in acquiring Mandarin is reading the Chinese characters (Ye, 2011). It is quite intimidating for the second language learners to grasp this logographic language system as it has thousands of characters to be memorized.

Besides that, among major problems in acquiring Mandarin language for non-native speakers is difficulties in reading Chinese pinyin (Dong, Tsubota \& Danstuji, 2013). Tonal errors pose a serious issue to the learners as pronouncing with different tones carries different meaning from the initial intention (Jongman, Wang, Moore \& Sereno, 2006). These condition leads to the unwillingness of the learners to converse the language.

Given the situations described above, these severe issues are feared to affect students' readiness in acquiring Mandarin language as a second language. Without proper intervention, the teaching and learning processes might somehow end up meaningless.

\section{The Secret Essence in Acquiring the Mandarin Language}

Eventually, learning Mandarin is not something that students need to sweat over grammar rules and trying to get it right every time they use the language. It is the fun in learning the language, along with the enjoyment of it and everything will falls perfectly during the process. In fact, innovation in improving the teaching and learning is not always about integrating technology into the curriculum (Hayes Jacobs, 2010). Incorporating cultures as one of the innovations in teaching and learning second language is something beyond imagination (Nault, 2008). It is like schools without walls; classrooms without boundaries.

According to Ellis (1999), in order for one to acquire the second language comprehensively, the learner should be fully immersed within the language. Nault (2008) also agreed that it is significant for the learners to become familiar with the target cultures in order to grasp the language proficiency completely. Integration of cultures into the curriculum is one of the best ways to structure instruction for a more meaningful learning which is by connecting the cultures to the learners' lives in the real world (Hill and Mannheim, 1992; Ding and Saunders, 2006).

There are various interesting and unique cultures that can be shared with the students to trigger their interests and readiness. For instance, the role of red color. According to Chinese, red symbolizes luck, prosperous, happiness and power (Huang, 2011). One of the creative ways to inculcate the importance of red color is by asking 
the students to wear red t-shirts during the examination day or any related events. By doing so, it is believe the students will be getting the positive aura, the passion and self-empowerment as what the Chinese believes.

Historically, China is the world's oldest continuous civilization. Tang poems are among the famous Classical Chinese literature (Lee \& Wong, 2012). What teachers can do is to allocate 2-3 minutes of total teaching hour for the recitation of Tang poems at beginning of the class. As result of doing this, students are not only able to feel what it is like during the Tang Dynasty, but also able to develop students' reading and speaking skills, along with boosting up their confidence level. Besides that, teachers can also provide the opportunity to write the Tang poems by using Chinese calligraphy brushes. These activities will attract the students' interests and at the same time able to enhance their readiness in acquiring the language.

According to research, classroom activities that are not contextualized and attached to real life issues, activities, and concerns, do not help the students learn to use second language (Firth \& Wagner, 1997; Hall, 1997; Stoller, 2006; van Lier, 2000, 2002). Therefore, the role of food as an essential part in human's life should never be forgotten (Tomalin and Stempleski, 1993; Lussier, 2011; Kramsh, 2013). Incorporating Chinese cultures through food as an innovation during the teaching and learning processes enhances students' readiness in acquiring Mandarin language (Stajcic, 2013). For example, when teaching something related to dining or food, teachers can organize a small cooking show with the kids in the classroom. Nothing fancy, just steam up the Chinese dumplings, pairs it up with Chinese tea and enjoys the dumplings by using chopsticks. The vibe of eating Chinese cuisine with chopsticks is unbelievable especially in capturing students' interests (Xiaoping, 2014). Even, one could go extra miles by bringing the students to a nearby Chinese restaurant. As the world becomes more globalized, it is not difficult to access authentic Chinese cuisines.

Apart from that, language teachers can use Mahjong as one way of innovations in teaching numbers. As mentioned earlier, acquiring Chinese characters can be really hard for Romanized language speakers. Therefore, by learning Chinese characters or numbers through "the game Chinese people played" is an innovative approach to attract students' interest and at the same time able to enhance students' readiness in acquiring Mandarin language (Greene, 2015). Playing Mahjong can enhance students' ability in terms of reading, speaking and listening comprehension skills as students need to able to read the Chinese characters on the Mahjong tiles, speak out the intended Chinese characters and listen to the other players' instruction while playing the games.

This kind of innovation in Mandarin language acquisition is highly required in the ever changing global landscape. Although many educators always look down on the importance of inculcating cultures through their teaching and learning methods as some of them thought it is very time consuming, however the impact of doing it is very spectacular. It is astounding on how cultures affect the students' learning. Thus, teachers must fasten up their seatbelts, gear up and ready to roll in facing the new global wave as Mandarin language is on the way in making its debut.

\section{Conclusions}

In a nut shell, learning Mandarin language is all about discovering the beauty of Chinese culture. The relationship between language and culture goes far deeper than we could imagine. Understanding language is understanding culture; the interdependence of language and culture is vital. Thus, it is very crucial for the teachers to bring along the students for a full gear of scuba diving, going down immersing through the Chinese cultures, while the students are encouraged to let the pulse of a new culture run through their veins and bring the language to life for a more meaningful learning. The successful of acquiring Mandarin language evolves in tandem with cultural understanding. Being able to master every bit of Chinese culture and in no time, students will be able to achieve native-like mastery of the language itself, which in this context, the students' readiness in Mandarin language acquisition can be greatly enhanced.

\section{REFERENCES}

[1] Abro, M., Zhenfang, L. \& Shabbir, R. (2014). Mandarin: Conquering the language classrooms around the world. American International Journal of Contemporary Research, 4(3), 48-54.

[2] Adelman, J. (2013). Why The U.S. Remains The World's Unchallenged Superpower. Forbes. Retrieved from https://www.forbes.com/sites/realspin/2013/11/24/why-the -u-s-remains-the-worlds-unchallenged-superpower/\#64dc1 $7305 \mathrm{~b} 6 \mathrm{e}$

[3] Amberg, J. S. \& Vause, D. J. (2009). American English: History, structure and usage. Cambridge: Cambridge University Press.

[4] Bernama (2018). Anwar urges Malay youths to master Mandarin. News Straits Times.

[5] Crystal, D. (2003). English as a Global Language. Cambridge: Cambridge University Press.

[6] David, C. S. (2006). Chinese as a lingua franca in Greater China. Annual Review of Applied Linguistics, 26, 149-176.

[7] Dearden, J. (2015). English as a medium of instruction: A growing global phenomenon. London: British Council.

[8] Dong, Y., Tsubota, Y. \& Dantsuji, M. (2013). Difficulties in perception and pronunciation of Mandarin Chinese 
disyllabic word tone acquisition: A study of some Japanese university students. Paper presented at 27 th Pacific Asia Conference on Language, Information and Computation.

[9] Drubin, D. G. \& Kellogg, D. R. (2012). English as the universal language of science: opportunities and challenges. Mol Biol Cell, 23 (8). Retrieved from https://www.ncbi.nlm.nih.gov/pmc/articles/PMC3341706/

[10] Duncan, H. D., Duncan, H. D. \& Wilder, C. N. (2017). Communication and social order. Somerset: Routledge.

[11] Fenton-Smith, B., Humphreys, P. \& Walkinshaw, I. (2018). English Medium Instruction in Higher Education in Asia Pacific from Policy to Pedagogy. Cham: Springer International Publishing.

[12] Goh, Y. (2016). Teaching Chinese as an international language a Singapore perspective. Cambridge: Cambridge University Press.

[13] Hayes Jacobs, H. (2010). Curriculum 21: Essential Education for a Changing World. Alexandria, VA: ASCD.

[14] Hong, L. \& Moreira, A. (2002). Is Chinese impossible to learn? An initiation into Chinese. Intercultural communication studies, 11 (3), 105-120.

[15] Huang, Q. (2011). A study on the metaphor of "red" in Chinese culture. American International Journal of Contemporary Research, 1 (3), 99-102.

[16] Jenkins, J. (2014). English as a Lingua Franca in the International University: The politics of academic English language policy. Milton Park (Abingdon, Oxon): Routledge.

[17] Jongman, A., Wang, Y., Moore, C. B. \& Sereno, J. A. (2006). Handbook of Chinese Psycholinguistics. Cambridge: Cambridge University Press.

[18] Khor Chun Keat (2018). Prime Minister's Department Dr Mujahid Yusof Rawa's daughter loves Chinese. Sin Chew Daily.

[19] Lee, J. \& Wong, T. (2012). Glimpses of Ancient China from Classical Chinese Poems. Paper presented at the COLING, Mumbai. fromhttp://www.aclweb.org/anthology/C12-2061

[20] McCarthy, N. (2018). The World's Most Spoken Languages. Statistica. Retrieved fromhttps:/www.statista.com/chart/12868/the-worlds-mos t-spoken-languages/

[21] Morrison, W. M. (2011). China-U.S. Trade Issues. Washington, D.C.: Library of Congress, Congressional Research Service.

[22] Nault, D. (2008). Going global: Rethinking culture teaching in ELT contexts. Language, culture and curriculum, 19 (3), 314-328.

[23] Neeley, T. (2012). Global Business Speaks English. Boston, MA: Harvard Business Review Press.

[24] Orwell, G. (2013). Politics and the English language. London: Penguin Books.

[25] Seidlhofer, B. (2015). Understanding English as a lingua franca. Oxford: Oxford University Press.
[26] Smokotin, V. M., Alekseyenko, A. S. \& Petrova, G. I. (2014). The Phenomenon of Linguistic Globalization: English as the Global Lingua Franca. Procedia - Social and Behavioral Sciences, 154 (1), 509-513.

[27] Spencer, W. A. (2015). Mandarin Chinese as a Second Language: A Review of Literature. Honors Research Projects, 210, 1-47.

[28] Stajcic, N. (2013). Understanding culture: Food as a means of communication. Hemispheres. Stud. Cult. Soc.,28, 77-87.

[29] Sulaiman, T. Ayub, A.F.M \& Sulaiman, S. (2015). Curriculum change in English language curriculum advocates higher order thinking skills and standards-based assessments in Malaysian primary schools. Mediterranean Journal of Social Sciences. 6(2), $494-500$

[30] Van Lier, L. (2002). An ecological-semiotic perspective on language and linguistics. In C. Kramsch (Ed.), Language acquisition and language socialization: Ecological perspectives, 140-164. London: Continuum.

[31] Ye, L. (2011). Teaching and learning Chinese as a foreign language in the United States: To delay or not to delay the character introduction 